\title{
Detection and identification of a Candidatus Liberibacter species from ash tree infesting psyllids
}

\author{
Francis Wamonje ${ }^{1}$, Ningxing Zhou ${ }^{1}$, Ramandeep Bamrah ${ }^{1}$, Tyler Wist ${ }^{2}$, and Sean Prager ${ }^{1}$ \\ ${ }^{1}$ University of Saskatchewan \\ ${ }^{2}$ Saskatoon Research and Development Centre
}

August 28, 2020

\begin{abstract}
Candidatus Liberibacter species cause severe, economically important diseases. All known species of these pathogens are putatively insect-transmitted, specifically by psyllids. Detection of Liberibacter in plants is complicated by its uneven distribution in host plants and largely unculturable nature. The death of black (Fraxinus nigra) and mancana (Fraxinus mandshurica) ash trees in Saskatchewan, Canada has been associated with infestation with the cottony ash psyllid (Psyllopsis discrepans). We hypothesized that the symptoms and death could be due to a psyllid-transmitted Liberibacter. We used a combination of conventional PCR and Sanger sequencing of the 16S rDNA for detection of Liberibacter, and the genes CO1 and Cyt-b to determine species of psyllids. The 16S sequencing generated two sequences, NTHA 5 (GenBank accession number MK942379) and NTHA 6 (GenBank accession number MK937570) that were 1058 and 1085 bp long. A BLAST search for homology showed 99-100\% sequence similarity to a Candidatus Liberibacter solanacearum sequence (GenBank accession number: KX197200) isolated from the Nearctic psyllid (Bactericera maculipennis) of US provenance. CO1 and Cyt-b gene sequencing of our psyllids yielded sequence information confirming that they were P. discrepans from comparisons with sequences in GenBank and BOLD. Confirmatory sequence comparison with a reference sample from the United Kingdom was concurrent. These results provide the first evidence on the likely cause of ash dieback in Saskatchewan. Further, they suggest a relatively rare example of a Liberibacter adapting a new host plant.
\end{abstract}

\begin{abstract}
Candidatus Liberibacter species cause severe, economically important diseases. All known species of these pathogens are putatively insect-transmitted, specifically by psyllids. Detection of Liberibacter in plants is complicated by its uneven distribution in host plants and largely unculturable nature. The death of black (Fraxinus nigra) and mancana (Fraxinus mandshurica) ash trees in Saskatchewan, Canada has been associated with infestation with the cottony ash psyllid (Psyllopsis discrepans). We hypothesized that the symptoms and death could be due to a psyllid-transmitted Liberibacter. We used a combination of conventional PCR and Sanger sequencing of the $16 \mathrm{~S}$ rDNA for detection of Liberibacter, and the genes CO1 and Cyt-bto determine species of psyllids. The $16 \mathrm{~S}$ sequencing generated two sequences, NTHA 5 (GenBank accession number MK942379) and NTHA 6 (GenBank accession number MK937570) that were 1058 and 1085 bp long. A BLAST search for homology showed 99-100\% sequence similarity to a Candidatus Liberibacter solanacearum sequence (GenBank accession number: KX197200) isolated from the Nearctic psyllid (Bactericera maculipennis ) of US provenance.CO1 and Cyt-b gene sequencing of our psyllids yielded sequence information confirming that they were $P$. discrepans from comparisons with sequences in GenBank and BOLD. Confirmatory sequence comparison with a reference sample from the United Kingdom was concurrent. These results provide the first evidence on the likely cause of ash dieback in Saskatchewan. Further, they suggest a relatively rare example of a Liberibacter adapting a new host plant.
\end{abstract}

Keywords : Psyllid, Ash disease, Candidatus Liberibacter species, DNA Barcoding, ecosystem jumping 


\section{Introduction}

The Candidatus $(\mathrm{Ca}$.) Liberibacter species are a group of mostly fastidious alpha proteo-bacteria. These species are associated with a series of devastating crop diseases including Zebra Chip (ZC) disease in potato (Crosslin et al. , 2011; Munyaneza, 2012), Vein Greening Disease in solanaceous crops (Crosslin et al. , 2010; Prager \& Trumble, 2018), infections in carrots (Bertolini et al. , 2015) and celery (Teresani et al. , 2014) and most importantly Huanglongbing (HLB) a.k.a. 'citrus greening' in various citrus species (Batool et al. , 2007; da Graca, 1991). Since it was first detected in Florida in 2005, HLB has resulted in losses worth hundreds of millions of dollars to the citrus industry (Spreen et al. , 2014). Zebra Chip disease was first detected in Mexico in 1994 (Munyaneza et al. , 2007), where it has also resulted in millions of dollars of losses (Greenway, 2014). Zebra chip disease has now been found in almost all of the western United States, parts of Canada, and New Zealand (Crosslin et al. , 2010; Kalischuk \& Johnson, 2019; Teulon et $a l$. , 2009). In Israel and parts of Europe, Ca.Liberibacter solanacearum is associated with Carrot Yellows Disease (Alfaro-Fernández et al. , 2012; Haapalainen et al. , 2017; Holeva et al. , 2017; Mawassi et al. , 2018; Munyaneza, 2012; Munyaneza et al. , 2015; Tahzima et al. , 2014). Finally, Ca. Liberibacter-associated diseases have been found in crops in the Umbelliferae family in Spain, Greece, and on the African continent in Morocco (Alfaro-Fernández et al. , 2012, 2017; Holevaet al. , 2017; Munyaneza, 2010; Nelson et al. , 2013; Tahzima et al. , 2014; Teresani et al. , 2014).

There are at least five known species of $C a$. Liberibacter, all of which have been identified through molecular techniques (Garnieret al. , 2000; Jagoueix et al. , 1996; Planet et al. , 1995). Three species, 'Ca. Liberibacter asiaticus' (CLas), 'Ca . L. americanus' (CLam), and 'Ca. L. africanus (CLaf)' are associated with HLB (Munyaneza, 2010). Two species are associated with asymptomatic plants, 'Ca. L. europaeus' (Leu) (Raddadiet al. , 2011) and 'Ca. L. crescens' (Lcr) (Leonardet al. , 2012). Finally, Candidatus Liberibacter solanacearum (CLso): AKA pyllaurous is associated with ZC and various other diseases of vegetables (Munyaneza, 2012). There are at least seven haplotypes of CLso designated A-F (Grimm \& Garczynski, 2019; Maucket al. , 2019). All known Ca. Liberibacter species are transmitted by one or more species of psyllid (Haapalainen, 2014; Munyaneza, 2010).

Psyllids are small phytophagous hemipteran, phloem feeding insects in the suborder Sternorrhyncha and superfamily Psylloidea (Hodkinson, 1988). It is currently unclear how specific the relationships between a given Liberibacter species and psyllid vector are, but some species can have more than one psyllid vector (Haapalainen, 2014). In addition to being the primary and usually exclusive vectors of $C a$.Liberibacter, psyllids are also common vectors of phytoplasmas, another group of mycoplasma-like bacterial plant pathogens (Ethmayer et al. , 2011; Jarausch et al. , 2019; Kaya et al. , 2016).

The cottony ash psyllid, Psyllopsis discrepans (Flor 1861) (Hemiptera: Psyllidae), is a specialist on several species ofFraxinus and is endemic to Europe. Its range, however, has included multiple reported introductions into North America (Hodkinson, 1988), including Nova Scotia, and multiple US States dating back to 1900s (USDA SEL Beltsville, MD, USA). Feeding by species ofPsyllopsis is often associated with pseudogalls (Hodkinson, 1974) but not tree death. In 2000, this insect was detected in the cities of Edmonton and Calgary, Alberta followed by the death of many of the city-owned black ash trees in 2005 that was attributed to a combination of drought and psyllid damage. They were next found in Saskatoon, Saskatchewan and later found in North and South Dakota and Montana. In all instances, the insects were found infesting Fraxinus nigra(Black Ash), Fraxinus manshurica (Mancana Ash) and their hybrids. As with other Psyllopsis- infested trees, these species often demonstrate pseudogalls but also exhibit a decreasing leaf canopy (Figure 1 ) and eventually die. While the precise cause of this plant dieback and death is currently unknown, it has been attributed to an "unknown toxin" in the saliva. This explanation has previously been applied to other psyllid-tree syndromes which have since been at least partially linked to a $\mathrm{Ca}$. Liberibacter species (Mauck et al. , 2019; Prager \& Trumble, 2018). Here we report a new association between a plant host and an insect-vecored pathogen where the pathogen range is likely determined by the range of the vector. 


\section{Materials and Methods}

\section{Collection of Psyllids}

Insects were trapped using standard or Asian Citrus Psyllid specific yellow colour sticky cards (Alpha Scents Inc., West Linn, OR) and by direct collection from trees via hand aspirators (Bioquip products, Rancho Dominguez, CA). Psyllid traps were deployed on Black (Fraxinus nigra), Mancana (F. mandshurica) and Hybrid ash trees owned and managed by the City of Saskatoon, the University of Saskatchewan Campus and Agriculture and Agri-Food Canada's Saskatoon Research and Development Centre. Traps were collected approximately every two weeks and stored at $4^{\mathrm{O}} \mathrm{C}$. As soon as possible, the psyllids were recovered from traps and transferred to $5 \mathrm{ml}$ glass vials containing $70 \%$ ethanol in the laboratory.

\section{Molecular detection, sequence comparisons and phylogeny of the Liberibacter sequences}

Molecular detection of Liberibacter was accomplished using 'general' Liberibacter primers (OA2 5'GCGCTTATTTTTAATAGGAGCGGCA-3' and OI2c 5'- GCCTCGCGACTTCGCAACCCA-3') that amplified a $1160 \mathrm{bp}$ region of the 16s ribosome gene as previously described (Jagoueix et al., 1996; Liefting et al. , 2009). Amplicons generated were subjected to automated Sanger sequencing. Sequences generated were checked for homology in the GenBank via BLAST. Multiple sequence alignments were done using MUSCLE in Molecular Evolutionary Genetics Analysis version 7.0 (MEGA 7) (Kumar et al. , 2016) and phylogeny inferred using the Neighbor-Joining method (Saitou \& Nei, 1987). The percentage differences between the nucleotide sequences of the isolates was obtained by a multiple sequence alignment with the MUSCLE algorithm in the Sequence Demarcation Tool software version 1.2 (Muhire et al. , 2014).

\section{Psyllid species identification by molecular markers}

DNA extraction was done using a DNeasy Blood and Tissue Kit (Qiagen GmbH, Mainz, Germany) and checked for quality using a Nanodrop ( ) spectrophotometer (Thermo Scientific, USA). PCR was done using the extracted DNA as a template, 2X Biomix Red@ (Bioline, UK) premix and universal primers for Cytochrome oxidase subunit 1 (CO1) LCO1490/ HCO2198 (Folmer et al. , 1994). Confirmatory identification by PCR was conducted in the laboratory of Dr. Diane Percy using DNA from our insect samples and a reference $P$. discrepanssample from her lab collection (a voucher specimen collected in Essex, UK). Primers used targeting CO1 were mtd6_F - 5'-GGA GGA TTT GGA AAT TGA TTA GTT CC-3' and mtd9_R 5'-CCC GGT AAA ATT AAA ATA TAA ACT TC-3' or H7005P_R primer 5'-TGA GCT ACT ACR TAR TAT GTR TCA TG-3'. Those targeting $C y t-b$ were CytB_F - 5'-TGA GGN CAA ATA TCH TTY TGA-3' and CytB_R - 5' GCA AAT ARR AAR TAT CAT TCDG- 3'. All amplicons generated were subjected to automated Sanger sequencing using appropriate primers. The sequences were checked for homology in GenBank and Bar Code of Life databases (BOLD).

\section{Results}

16s gene sequences showed closest similarity to Candidatus Liberibacter solanacearum (psyllaurous) sequences

DNA from 20 psyllid samples from the trees were subjected to $16 \mathrm{~S}$ gene sequencing, and of these, 11 showed the presence of $C a$.Liberibacter (Table 1 ). Two samples, named NTHA 5 and NTHA 6, generated two high quality sequences which were that were 1058 and 1085 bp long, respectively (Table 1). These were deposited in GenBank (NTHA 5; GenBank accession number MK942379 and NTHA 6; GenBank accession number MK937570). A BLAST search for homology for these two sequences showed 99-100\% sequence similarity to a Ca.Liberibacter solanacearum sequence (GenBank accession number: KX197200) isolated from a Nearctic psyllid (Bactericera maculipennis) from the US.

Phylogenetic reconstruction of evolutionary differences was conducted using sequences from GenBank representing different Liberibacter subspecies from different geographical locations and the NTHA 5 and NTHA 
6 sequences (Supplementary Table 1 ). Though the other samples showed the presence of $\mathrm{Ca}$. Liberibacter, the sequences generated were not of sufficient quality for use in phylogenetic analyses. Due to limited template, we were not able to repeat the PCR or sequencing. Phylogenetic analyses revealed four distinct clades based on subtypes and our samples clustered in the same clade with CLSo (Figure 2 ).

Pairwise comparisons of nucleotide sequences revealed sequence variation among the subspecies represented. The two samples from our study (NTHA5 and NTHA6) shared $99.9 \%$ nucleotide sequence similarity. The two sequences had closest similarity (approximately 94.4\%), with $C a$.Lib solanacearum sequences and were most dissimilar from those of $\mathrm{Ca}$. Lib. americanus (approximately 54\%) (Figure 3, Supplementary Table 2 ).

\section{COI sequencing of psyllids suggests that psyllids on Ash trees are the cottony ash psyllid}

Species identification by $C O I$ sequencing of psyllid samples collected from the same trees was done. Of these, 11 samples were successfully amplified and sequenced. A BOLD database search for similar sequences found ten samples $(n=10)$ to be of the order Hemiptera and family Liviidae, with sequence similarities ranging from $98 \%-100 \%$. Also, BLAST searches in the GenBank nucleotide database found all samples to be of the species $P$. discrepans, with homology ranges of 99.83\%-100\% (Table 2 )

One of these samples, NTHA 5, which had tested positive for $C a$.Liberibacter and for which there was sufficient DNA template, was sent $C O I$ and $C y t$ - $b$ gene sequencing for independent confirmation of species identity against a reference species. The pairwise comparison revealed $100 \%$ sequence similarity between our sample and the reference $P$. discrepans sample. BLAST searches of $C O 1$ showed over $99.5 \%$ similarity to $P$. discrepans isolates of Swedish and Canadian origins (GenBank id: MT021807.1 and MF958492.1 respectively). The Cyt-b sequences showed $87.21 \%$ similarity to P. repens(GenBank ID: MG989141.1) and $86.42 \%$ to P. flaxini (GenBank id: MG989139.1). This discrepancy may be due to the absence of $C y t$-bsequences for $P$. discrepans in GenBank. The percentage differences are indicative of clear species demarcation.

\section{Discussion}

Presented here is the first report of $\mathrm{Ca}$. Liberibacter extracted from cottony ash psyllid (Psyllopsis discrepans ) collected from ash trees. Following these results, a broader reaching survey of psyllids for $\mathrm{Ca}$. Liberibacter has been initiated, and traps have now been deployed to collect psyllids in Saskatchewan and other provinces in Canada where ash death has been identified. A new design of 3D-printed traps is now in use to better preserve the trapped insects (Horton et al., 2019). It was observed that the psyllids trapped on sticky cards degrade leading to low DNA recovery during extractions. This is also a known phenomenon with HLB and psyllid samples (Dr Sean Prager: Personal Communication).

From the data generated in this study, out best sequences grouped phylogenetically with CLso and had 99-100\% sequence similarity in BLAST. Further, our sequences most closely matched a sequence of CLso extracted from the psyllid Bactericera maculipennis collected in Washington State USA. Previous detections of CLso have been from either vegetable crops or other wild solanaceous plants. In contrast, multiple other species of Liberibacter are associated with perennial trees in theRutaceae (Halbert \& Keremane, 2004) and one species, L. crescens, is associated with Babaco mountain papaya (Carica stipulata $\times$ C. pubescens ) (Leonard et al. , 2012). The sequences presented here were extracted from psyllids, not plants, but as the insects were collected from ash trees, it is suggestive that this may be a new host for CLso.

The results presented here indicate strong genetic homology between psyllid specimens collected from infested trees in Saskatchewan and cottony ash psyllids. These genetic results are further supported by the samples sent to Dr. Diana Percy that were sequenced and compared to a known sample collected in Kent UK; the specimens were an exact genetic match based on $C O I$ and $C y t-b$ sequences. From the early 2000s, cities in western Canada and the United States began to suffer the loss of ash trees which were infested with a species of psyllid assumed to be the cottony ash psyllid. Collectively, this would indicate that those psyllids infesting ash trees in Western Canada are P. discrepans. This species is not endemic to North America despite having 
been known in North America for over 100 years (Hodkinson, 1988). It is therefore likely that the infestation in western Canada and the United States is the result of introduction from either an established population in eastern North America or Europe.

The results presented here of $P$. discrepans collected from dying ash trees have important implications for both the biology of psyllid-Liberibacter pathosystems and in the context of ash loss in western Canada and the United States. These findings indicate that the loss of trees may be the result of infection with CLso rather than the effect of psyllid feeding alone. It is known that $P$. discrepansfeeding causes leaf symptoms in ash, including rolled leaflets, reddening of leaf borders, and leaf swelling. Psyllopsis discrepans infestation also results in pseudogalls on infested trees (Burckhardt, 1994). Notably, while similar symptoms are observed in infested ash trees in western Canada, these trees also exhibit progressive defoliation over two to three seasons, eventually resulting in complete defoliation within four years (unpublished data). This progressing defoliation can be compared to HLB disease, which is also a disease in trees and often results in defoliation, dieback, and eventual death (Hu et al. , 2011). Notably, though it has been determined that citrus plants can become infectious with HLB 10-15 days post-inoculation by psyllids, the plant can remain asymptomatic for years while infected and not much is known about where the bacteria localizes in planta (Ann et al. , 2015). While the fastidious nature of all known $C a$. Liberibacter species (other than $C a$. Liberibacter crescens) complicates detection in plants; this can possibly be overcome through a combination of grafting experiments and PCR.

It is however highly likely that the extreme symptoms observed in psyllid infested ash trees in western Canada are also a result of $\mathrm{Ca}$. Liberibacter infection transmitted by psyllids. In addition to describing a potential cause of ash loss, the findings presented here have direct implications for disease ecology and epidemiology. Transmission of Liberibacters across plant species by a single psyllid species is possible, though this is dependent on the transmission efficiency of the psyllid on and the ability of the bacteria to establish infection in the new host plant (Chaves de et al. , 2020). We hypothesize that an introduced population of P. discrepans may have acquired CLSo while sharing a common host plant with a population of Bactericera maculipennis. This shared host plant likely would have been field bindweed (Convolvulus arvensis, Solanales: Convolvulaceae) which is known to be co-inhabited by multiple psyllid species including B. maculipennis from which CLSo has been extracted previously (Borges et al. , 2017).Bactericera maculipennis has a known geographical range that includes the US states of Washington, Idaho, Oregon, and Montana (Hortonet al. , 2017). Montana and Idaho both border Alberta, where these psyllids and the ash disease were both initially detected, while infected B. maculipennis was collected in Washington (Borgeset al. , 2017). If this hypothesis is correct, this will be a somewhat rare example of a mycoplasma-like pathogen adopting a new vector and consequently a new host plant in what is a rather dramatic host shift. Furthermore, it also suggests that $C a$. Liberibacter species may not be particularly host specific and that the actual restriction to their host range is the biology of their psyllid vectors. Collectivey, this is simiar to the "ecosystem jumping" pehenomenon descrived by da Graca et al. (2016); although, extraction and sequencing form infected plants will be required to further support this. Unfortunately, this is difficult process in trees as evidenced by multiple examples in the citrus and HLB pathosystem (Merfa et al., 2019; Valdés et al. , 2016).

\section{Acknowledgements}

We thank Drs. Diana Percy and David Horton for confirmation of psyllid identity. This work was supported by an NSERC Discovery Grant to SMP.

\section{References}

Alfaro-Fernández, A., Cebrian, M. C., Villaescusa, F. J., Hermoso de Mendoza, A., Ferrandiz, J. C., Sanjuán, S. \& Font, M. I.(2012). First report of 'Candidatus Liberibacter solanacearum' in carrot in mainland spain. Dis Notes $\mathbf{9 6}, 11-12$.

Alfaro-Fernández, A., Verdeguer, M., Rodríguez-león, F., Ibáñez, I., Hernández, D., Teresani, 
G. R. \& Bertolini, E. (2017).Search for reservoirs of 'Candidatus Liberibacter solanacearum ' and mollicutes in weeds associated with carrot and celery crops. Eur J Plant Pathol 147, 15-20. European Journal of Plant Pathology.

Ann, J., Halbert, S. E., Dawson, W. O., Robertson, C. J., Keesling, J. E. \& Singer, B. H. (2015). Asymptomatic spread of huanglongbing and implications for disease control. Proc Natl Acad Sci U $S A 112,7605-7610$.

Batool, A., Iftikhar, Y., Khan, M. M., Jaskani, M. J., Abbas, M. \& Khan, I. A. (2007). Citrus Greening Disease - A major cause of citrus decline in the world - A Review. Hortic Sci34 , 159-166.

Bertolini, E., Teresana, G. R., Tanaka, F. A. O., Barbe, S., Martinez, C., Gentit, P., Lopez, M. M. \& Cambra, M. (2015).Transmission of 'Candidatus Liberibacter solanacearum' in carrot seeds.Plant Pathol 64, 276-285.

Borges, K. M., Cooper, W. R., Garczynski, S. F., Thinakaran, J., Jensen, A. S., Horton, D. R., Munyaneza, J. E., Cueva, I. \& Barcenas, N. M. (2017). Insect-symbiont interactions "Candidatus Liberibacter solanacearum" associated with the psyllid, Bactericera maculipennis (Hemiptera: Triozidae ). Environ Entomol46 , 210-216.

Burckhardt, D. (1994). Psylloid pests of temperate and subtropical crop and ornamental plants (Hemiptera, Psylloidea): A review. Trends Agric Sci 2 , 173-186.

Chaves de, M. Q.-G., Teresani, G. R., Hernandez-Suarez, E., Bertolini, E., Fereres, A. \& Cambra, M. (2020). ' Candidatus Liberibacter Solanacearum ' Is Unlikely to Be Transmitted Spontaneously from Infected Carrot Plants to Citrus Plants by Trioza Erytreae.Insects 11, 514 .

Crosslin, A. J. M., Lin, H. \& Munyaneza, J. E.(2011). Detection of 'Candidatus Liberibacter Solanacearum' in the Potato Psyllid, Bactericera cockerelli (Sulc) 1, by Conventional and Real-Time PCR. Southwest Entomol 36 , 125-135.

Crosslin, J. M., Munyaneza, J. E., Brown, J. K. \& Liefting, L. W. (2010). Potato zebra chip disease: A phytopathological tale. Plant Heal Prog .

Ethmayer, C. L., Ausdorf, H. H., Ahecha, B. S. U. \& Eisenzein, H. R. (2011). The importance of psyllids (Hemiptera Psyllidae) as vectors of phytoplasmas in pome and stone fruit trees in Austria.Bull Insectology $64,255-256$.

Folmer, O., Black, M., Hoeh, W., Lutz, R. \& Vrijenhoek, R.(1994). DNA primers for amplification of mitochondrial cytochrome c oxidase subunit I from diverse metazoan invertebrates. Mol Mar Biol Biotechnol 3, 294-299.

Garnier, M., Jagoueix-Eveillard, S., Cronje, P. R., Le Roux, H. F. \& Bové, J. M. (2000). Genomic characterization of a liberibacter present in an ornamental rutaceous tree, Calodendrum capense, in the Western Cape province of South Africa. Proposal of 'Candidatus liberibacter africanus subsp. capensis'. Int J Syst Evol Microbiol 50, 2119-2125.

da Graca, J. V . (1991). Citrus greening disease.Annu Rev Phytopathol 29 , 109-136.

Greenway, G. (2014). Economic impact of Zebra chip control costs on grower returns in seven US states. Am J Potato Res 91, 714-719.

Grimm, K. D. S. \& Garczynski, S. F. (2019).Identification of a new haplotype of 'Candidatus Liberibacter solanacearum' in Solanum tuberosum. Plant Dis 103, 468-474.

Haapalainen, M. (2014). Biology and epidemics of Candidatus Liberibacter species, psyllid-transmitted plant-pathogenic bacteria. Ann Appl Biol 165 , 172-198. 
Haapalainen, M., Kivimaki, S., Latvala, S., Rastas, M., Hannukkala, A., Jauhianen, L., Lemmety, A., Pirhonen, M., Virtanen, A. \& Nissinen, A. I. (2017). Frequency and occurrence of the carrot pathogen ' Candidatus Liberibacter solanacearum ' haplotype C in Finland. Plant Pathol 559-570.

Halbert, S. E. \& Keremane, L. (2004). Asian citrus psyllids (Sternorrhyncha: Psyllidae) and greening disease of citrus: A literature review and assessment of risk in Florida. Florida Entomol 87 , 330-353.

Hodkinson, I. D. (1974). The biology of the Psylloidea (Homoptera): A review. Bull Entomol Res 64 , 325-338. University of Cambridge.

Hodkinson, I. D. (1988). The Nearctic Psylloidea (Insecta: Homoptera ): an annotated check list. $J$ Nat Hist 22, 1179-1243.

Holeva, M. C., Glynos, P. E. \& Karafla, C. D. (2017).First report of 'Candidatus Liberibacter solanacearum' on carrot in Greece. Plant Dis $\mathbf{1 0 1}$.

Horton, D. R., Miliczky, E., Tamera, L. M., Rodney, C. W., Munyaneza, J. E., Mustafa, T., Thinakaran, J., Waters, T. D., Wohleb, C. H. \& Jensen, A. S. (2017). New geographic records for the nearctic psyllid Bactericera maculipennis (Crawford) with biological notes and descriptions of the egg and fifth-instar nymph (Hemiptera: Psylloidea: Triozidae). Proc Entomol Soc Washingt 119 , 191-214.

Horton, D. R., Miliczky, E. R., Lewis, T. M., Wohleb, C. H., Waters, T. D., Dickens, A. A., Halbert, S. E., Ramadugu, C. \& Jensen, A. S. (2019). Building a better Psylloidea (Hemiptera) trap? A field-look at a prototype trap constructed using three-dimensional printer technology. Can Entomol $151,115-129$.

Hu, L., Huang, T., Liu, X. \& Cai, Y. (2011).Predicting protein phenotypes based on protein-protein interaction network. PLoS One $\mathbf{6}$, e17668.

Jagoueix, S., Bove, J. M. \& Garnier, M. (1996). PCR detection of the two 'Candidatus' liberobacter species associated with greening disease of citrus. Mol Cell Probes 10 , 43-50.

Jarausch, B., Tedeschi, R., Sauvion, N., Gross, J. \& Jarausch, W. (2019). Psyllid Vectors. In Phytoplasmas Plant Pathog Bact II , pp. 53-78.

Kalischuk, M. \& Johnson, D. L. (2019). First report of zebra chip on potato in Canada. Plant Dis 103 , 5 .

Kaya, K., Serce, C., Gazel, M., Caglayan, K., Kaya, K., Serce, Ç., Gazel, M., Caglayan, K. \& Sauvion, N. (2016). Potential psyllid vectors of ' Candidatus Phytoplasma mali and Candidatus Phytoplasma pyri in Turkey. Pakistan Assoc Adv Agric Sci53, 383-392.

Kumar, S., Stecher, G. \& Tamura, K. (2016). MEGA7 : Molecular Evolutionary Genetics Analysis Version 7 . 0 for Bigger Datasets Brief communication 33, 1870-1874.

Leonard, M. T., Fagen, J. R., Davis-richardson, A. G. \& Davis, M. J. (2012). Complete genome sequence of Liberibacter crescens BT-1. Stand Genomic Sci 7 , 271-283.

Liefting, L. W., Sutherland, P. W., Paice, K. L., Weir, B. S. \& Clover, G. R. G. (2009). A new 'Candidatus Liberibacter' Species associated with diseases of Solanaceous crops. Plant Dis 93 , 208-214.

Mauck, K. E., Sun, P., Meduri, V. R. \& Hansen, A. K.(2019). New Ca. Liberibacter psyllaurous haplotype resurrected from a 49-year-old specimen of Solanum umbelliferum: a native host of the psyllid vector. Sci Rep 9 , 9530. Springer US.

Mawassi, M., Dror, O., Piasezky, A., Sj, J. M., Levitzky, N., Shoshana, N., Meslenin, L., Haviv, S., Porat, C. \& other authors .(2018). 'Candidatus Liberibacter solanacearum' is tightly associated with carrot yellows symptoms in Israel and transmitted by the prevalent psyllid vector Bactericera trigonica. Phytopathology108, 1056-1066. 
Merfa, M. V, Lopez-Perez, E., Naranjo, E., Jain, M., Gabriel, D. W. \& Fuente, L. D. La . (2019). Progress and obstacles in culturing 'Candidatus Liberibacter asiaticus' the bacterium associated with Huanglongbing. Phytopathology 109 , 1092-1101.

Muhire, B. M., Varsani, A. \& Martin, D. P. (2014).SDT: A virus classification tool based on pairwise sequence alignment and identity calculation. PLoS One $\mathbf{9}$.

Munyaneza, J. E., Crosslin, J. M. \& Upton, J. E.(2007). Association of Bactericera cockerelli (Homoptera: Psyllidae ) with "Zebra Chip," a new potato disease in Southwestern United States and Mexico. J Econ Entomol 100, 656-663.

Munyaneza, J. E., Swisher, K. D., Hommes, M., Willhauck, A., Buck, H. \& Meadow, R. (2015). First report of 'Candidatus Liberibacter solanacearum' associated with psyllid-infested carrots in Germany. Plant Dis 99 , 15-16.

Munyaneza, J. E. (2010). Psyllids as vectors of emerging bacterial diseases of annual crops. Southwest Entomol35 , 471-477.

Munyaneza, J. E. (2012). Zebra chip disease of potato: Biology, epidemiology, and management. Am $J$ Potato Res89 , 329-350.

Nelson, W. R., Munyaneza, J. E., McCue, K. F. \& Bove, J. M.(2013). The Pangaean origin of 'Candidatus Liberibacter' species. J Plant Pathol 95 , 455-461.

Planet, P., Jagoueix, S., Bove, J. M. \& Garnier, M.(1995). Detection and characterization of the African citrus greening Liberobacter by amplification, cloning, and sequencing of the rplKAJL-rpoBC operon. Curr Microbiol 30, 137-141.

Prager, S. M. \& Trumble, J. T. (2018). Psyllids: Biology, ecology and management. In Sustain Manag Arthropod Pests Tomato, pp. 163-181.

Raddadi, N., Gonella, E., Camerota, C., Pizzinat, A., Tedeschi, R., Crotti, E., Mandrioli, M., Bianco, P. A., Daffonchio, D. \& Alma, A. (2011). 'Candidatus Liberibacter europaeus' sp. nov. that is associated with and transmitted by the psyllid Cacopsylla pyri apparently behaves as an endophyte rather than a pathogen. Environ Microbiol $13,414-426$.

Saitou, N. \& Nei, M. (1987). The neighbour-joining method: a new method for reconstructing phylogenetic trees. Mol Biol Evol 4, 406-425.

Spreen, T. H., Mcca, H. A., Box, P. O., Baldwin, J. \& Futch, S. H. (2014). An economic assessment of the impact of Huanglongbing on citrus tree plantings in Florida. HortScience49 , 1052-1055.

Tahzima, R., Maes, M., Achbani, E. H., Swisher, K. D., Munyaneza, J. E. \& Jonghe, K. De . (2014). First Report of 'Candidatus Liberibacter solanacearum' on Carrot in Africa. Plant Dis 98 , 10.

Teresani, G. R., Bertolini, E., Alfaro-Fernandez, A., Martinez, C., Andre, F., Tanaka, O., Kitajima, E. W., Sanjuan, S., Ferrandiz, J. C. \& other authors . (2014). Association of 'Candidatus Liberibacter solanacearum' with a vegetative disorder of celery in Spain and development of a real-time PCR method for its detection.Phytopathology 104, 804-811.

Teulon, D. A. J., Workman, P. J., Thomas, K. L. \& Nielsen, M.-C. (2009). Bactericera cockerelli: Incursion, dispersal asn current distribution on vegetable crops in New Zealand. New Zeal Plant Prot Soc $144,136-144$.

Valdes, R. A., Ortiz, J. C. D., Beache, M. B., Cabello, J. A., Chavez, E. C. \& Pagaza, Y. R. (2016). A review of techniques for detecting Huanglongbing (greening) in citrus. Can J Microbiol811, 803-811. 


\section{Data Accessibility}

Sequences for samples NTHA 5 (GenBank accession number MK942379) and NTHA 6 (GenBank accession number MK937570) are publicly available in GenBank.

\section{Author contributions}

SMP designed the research; FOW, NZ, RB and TW performed research. TW contributed reagents and data. FOW and SP analysed the Data. FOW and SP wrote the paper. All authors approved of the final submitted manuscript.

Table 1: Detection of Ca.Liberibacter-like sequences in psyllids

\begin{tabular}{|c|c|c|c|c|c|c|}
\hline Sample & Host Plant & $\begin{array}{l}\text { Sequencing } \\
\text { Primer }\end{array}$ & $\begin{array}{l}\text { Sequence } \\
\text { length }\end{array}$ & $\begin{array}{l}\text { Closest } \\
\text { BLAST } \\
\text { using FWD } \\
\text { primer } \\
\text { sequence }\end{array}$ & $\begin{array}{l}\text { BLAST } \\
\text { identity (\%) }\end{array}$ & $\begin{array}{l}\text { GenBank } \\
\text { Number of } \\
\text { closest } \\
\text { identity }\end{array}$ \\
\hline LB 3 & $\begin{array}{l}\text { Mancana } \\
\text { ash }\end{array}$ & $\mathrm{AO} 2$ & 420 & $\begin{array}{l}\text { Ca. Lib. } \\
\text { solanacearum }\end{array}$ & 99.5 & MG701017.1 \\
\hline NTHA 1 & $\begin{array}{l}\text { Northern } \\
\text { Treasure } \\
\text { Hybrid }\end{array}$ & $\mathrm{AO} 2$ & 245 & $\begin{array}{l}\text { Ca. Lib. } \\
\text { solanacearum }\end{array}$ & 99.11 & KX185608.1 \\
\hline NTHA 2 & $\begin{array}{l}\text { Northern } \\
\text { Treasure } \\
\text { Hybrid }\end{array}$ & $\mathrm{AO} 2$ & 290 & $\begin{array}{l}\text { Ca. Lib. } \\
\text { solanacearum }\end{array}$ & 99.19 & KX185608.1 \\
\hline NTHA 4 & $\begin{array}{l}\text { Northern } \\
\text { Treasure } \\
\text { Hybrid }\end{array}$ & $\mathrm{AO} 2$ & 478 & $\begin{array}{l}\text { Ca. Lib. } \\
\text { solanacearum }\end{array}$ & 97.03 & KX185608.1 \\
\hline NTHA 5 & $\begin{array}{l}\text { Northern } \\
\text { Treasure } \\
\text { Hybrid }\end{array}$ & $\mathrm{AO} 2$ & 1058 & $\begin{array}{l}\text { Ca. Lib. } \\
\text { solanacearum }\end{array}$ & 100 & KX197200 \\
\hline NTHA 6 & $\begin{array}{l}\text { Northern } \\
\text { Treasure } \\
\text { Hybrid }\end{array}$ & $\mathrm{AO} 2$ & 1085 & $\begin{array}{l}\text { Ca. Lib. } \\
\text { solanacearum }\end{array}$ & 99.91 & KX197200 \\
\hline Y1 & Mancana & $\mathrm{AO} 2$ & 1096 & $\begin{array}{l}\text { Ca. } \\
\text { Liberibacter }\end{array}$ & $98.18 \%$ & FJ914619.1 \\
\hline Y2 & Mancana & $\mathrm{AO} 2$ & 450 & $\begin{array}{l}\text { Ca. } \\
\text { Liberibacter }\end{array}$ & $100 \%$ & FJ395219.1 \\
\hline Y4 & Mancana & $\mathrm{AO} 2$ & 854 & $\begin{array}{l}\text { Ca. } \\
\text { Liberibacter }\end{array}$ & $99.76 \%$ & FJ914619.1 \\
\hline Y6 & Mancana & $\mathrm{AO} 2$ & 373 & $\begin{array}{l}\text { Ca. Lib. } \\
\text { solanacearum }\end{array}$ & $99.72 \%$ & MN396643.1 \\
\hline Y10 & Mancana & $\mathrm{AO} 2$ & 618 & $\begin{array}{l}\text { Ca. } \\
\text { Liberibacter }\end{array}$ & $99.19 \%$ & FJ914619.1 \\
\hline
\end{tabular}

Table 2: BOLD and BLAST searches for $C O I$ sequences from psyllids

\begin{tabular}{|c|c|c|c|c|c|}
\hline Sample ID & & BOLD & Probability & BLAST & Probability \\
\hline DowRd 1-1 & Mancana ash & Hemiptera liviidae & $100 \%$ & Psyllopsis discrepans & $100 \%$ \\
\hline
\end{tabular}




\begin{tabular}{|c|c|c|c|c|c|}
\hline Sample ID & & BOLD & Probability & BLAST & Probability \\
\hline DowRd 1-2 & Mancana ash & Hemiptera liviidae & $98 \%$ & Psyllopsis discrepans & $100 \%$ \\
\hline DowRd 1-3 & Mancana ash & Hemiptera liviidae & $98.55 \%$ & Psyllopsis discrepans & $99.83 \%$ \\
\hline DowRd 2-1 & Mancana ash & Hemiptera liviidae & $98.77 \%$ & Psyllopsis discrepans & $99.85 \%$ \\
\hline DowRd 2-2 & Mancana ash & Hemiptera liviidae & $100 \%$ & Psyllopsis discrepans & $100 \%$ \\
\hline DowRd 2-3 & Mancana ash & Hemiptera liviidae & $99.83 \%$ & Psyllopsis discrepans & $99.85 \%$ \\
\hline DowRd 3-1 & Mancana ash & Hemiptera liviidae & $100 \%$ & Psyllopsis discrepans & $100 \%$ \\
\hline DowRd 3-2 & Mancana ash & Hemiptera liviidae & $98.77 \%$ & Psyllopsis discrepans & $100 \%$ \\
\hline DowRd 3-3 & Mancana ash & Hemiptera liviidae & $98.77 \%$ & Psyllopsis discrepans & $100 \%$ \\
\hline NTHA 5 & Northern Treasure Hybrid & Hemiptera liviidae & 99.78 & Psyllopsis discrepans & $99.7 \%$ \\
\hline UK Ref. & unknown & Hemiptera liviidae & 99.78 & Psyllopsis discrepans & $99.5 \%$ \\
\hline
\end{tabular}

\section{FIGURE CAPTIONS}

Figure 1: Typical disease symptoms and psyllids on ash tree.

Panel 'A': Leaf deformation caused by the disease on ash trees. Panel 'B': Psyllids were present on the leaves (red arrow), and there was the characteristic 'cotton' like depositions on the leaves (black arrow). Panel 'C': Completely defoliated ash tree associated with psyllid infestation.

Figure 2: Evolutionary relationships of different Liberibacter subspecies.Sequences used in this analysis were generated from the $16 \mathrm{~s}$ ribosomal gene. Phylogenetically, they clustered in five clades (A-E) according to subtype. Sequences from our study (highlighted in the red box) clustered with $\mathrm{Ca}$. Liberibacter solanacearum sequences in clade ' $\mathrm{D}$ '. The evolutionary history was inferred using the Neighbor-Joining method with bootstrapping (1000 replicates). Evolutionary distances were computed using the Kimura 2-parameter conducted in MEGA7.

Figure 3: Percentage pairwise sequence comparison of Liberibacter subspecies.Sequences from our study (red box) showed closest similarity to those of Candidatus Liberibacter solanacearum (grey box). They were most dissimilar to those of Candidatus Liberibacter americanus (light green colour). The computed percentages are shown in the additional information (Supplementary Table 2)
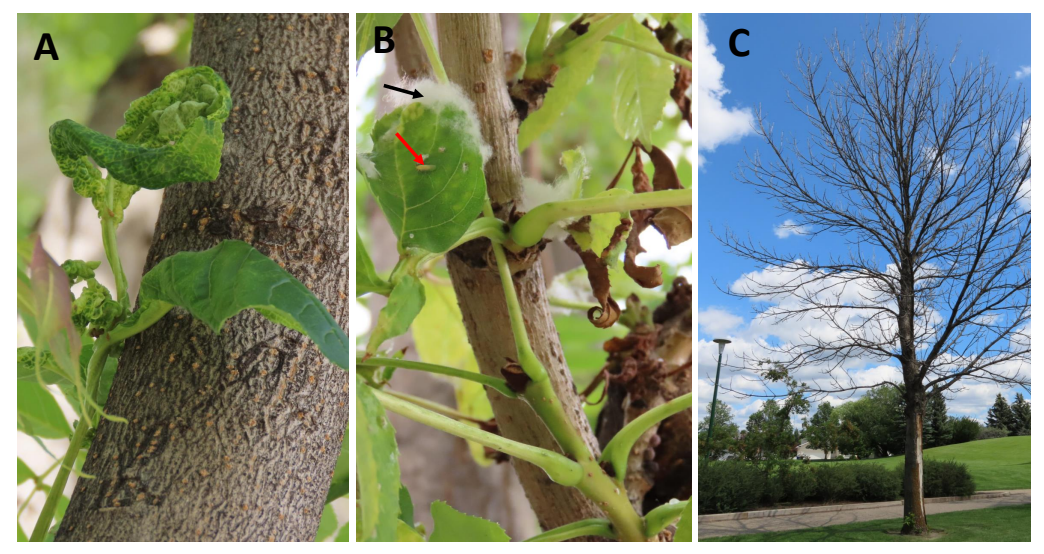

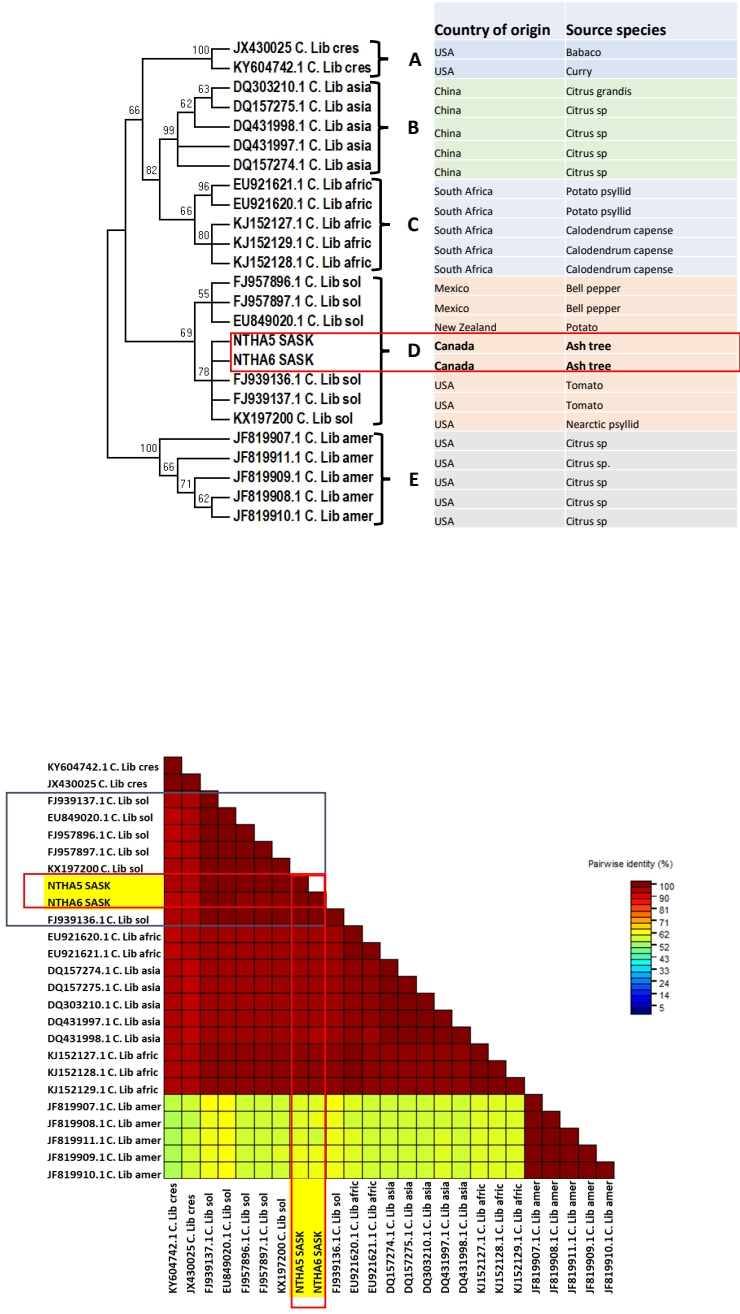